\title{
К вопросу создания эффективных тепловых узлов установок выращивания монокристаллов германия
}

\author{
К.Е. Аношин, А.В. Наумов, В.В. Старцев \\ Акиионерное общество «Оптико-механическое конструкторское бюро «АСТРОН», \\ Московская область, г. Лыткарино, 140080, ул. Парковая, 1 \\ тел./факс: +7 (495) 941-6272, эл.nочта: v@astrohn.ru
}

DOI 10.34077/RCSP2019-99

Полупроводники на основе германия, являются чрезвычайно перспективными для использования в микроэлектронике, оптоэлектронике, солнечной энергетике и ИК оптике. Известен широкий ряд технических решений, направленных на усовершенствование теплового узла устройств для выращивания монокристаллов из расплава методом Чохральского. Тепловые узлы современных установок выращивания монокристаллов имеют, как правило, открытое для свободного излучения зеркало расплава. Это приводит к значительным (до 46\%) потерям мощности установки. Известны также тепловые узлы, в которых используется конические экраны («колодцы»), опирающиеся на горизонтальные экраны. Над расплавом создается замкнутая полость, препятствующая излучению от охлаждаемых стенок камеры. Однако, такая конструкция сужает поле зрение оператора, которому необходимо видеть свободную поверхность расплава, для вмешательства вплоть до повторения процесса затравления в случае неудачного начала. И в том и в другом случае наблюдаются повышенные значения градиентов температур и термоупругих напряжений в кристалле. [1-3]

Нами разработан плавающий на поверхности расплава экран специальной конструкции. Тепло, передаваемое кольцевым плавающим экраном от расплава на поверхность растущего слитка, улучшает симметричность радиального температурного распределения на поверхности расплава. Размеры и материал плавающего экрана подобраны таким образом, чтобы его масса и теплопроводность обеспечивали необходимое выделение тепловой энергии над расплавом в области фронта кристаллизации при росте монокристаллов, но при этом не происходило нарушение конвекционных потоков в расплаве за счет погружения экрана в расплав. Техническим результатом применения плавающего экрана, является создание тепловых условий в области фронта кристаллизации, обеспечивающих равномерное распределение температур, для получения кристаллов больших диаметров, имеющих плотность дислокаций менее $200 \mathrm{~cm}^{-2}$ и равномерное распределение в объеме легирующих примесей. [4]

\section{Лumepamypa}

[1] И.А. Каплунов, А.И. Колесников, Е.И. Каплунова. Выращивание крупногабаритных монокристаллов германия для инфракрасной оптики. Journal of Siberian Federal University. Engineering \& Technologies 3 (2013 6) 324-333.

[2] И.С. Гейдт, Е.Д. Кравцова, О.И. Подкопаев «Влияние мощности экрана-нагревателя, а процессы тепло и массопереноса при получении малодислокационных кристаллов германия методом Чохральского» // Новый университет, 2013, №11-12, с. 54-60.

[3] Оптимизация конструкции теплового экрана в установке "Редмет-30" для выращивания низко дислокационных кристаллов германия диаметром свыше 100 мм - К.Е. Аношин, О.М. Алимов, А.В. Наумов - XI Конференция и X Школа молодых ученых и специалистов по актуальным проблемам физики, материаловедения, технологии и диагностики кремния, нано метровых структур и приборов на его основе КРЕМНИЙ-2016». 12-16 сентября 2016 г., Новосибирск.

[4] Заявка рег№ 2019108025 от 20.03.2019 (РФ). «Устройство для выращивания бездислокационного монокристалла из расплава» К. Е. Аношин, А.В. Наумов, В.В. Старцев (на оформлении, вх № 015511) 2019. 